\title{
The meaning of research, writing a research paper, and publication
}

Deuk-Sang Ma

The President of the Korean Academy of Preventive Dentistry and Oral Health

The theme of the 2020 Korean Academy for Preventive Dentistry and Oral Health General Conference is "Exploring the integration of public oral health and preventive dentistry in the fourth industrial revolution." As the word "fourth", implies, the first to third industrial revolutions must exist beforehand in order for the fourth revolution to exist.

Similarly, the existence of our generation was possible because the previous generations created the foundation. Therefore, the existence of the next generation will be possible only if our generation creates the foundation for them as well. What is the ultimate goal of conducting research, writing a paper, and publishing it? It is to help humanity lead a healthy life to create a better future and a better future generation. By reading published papers, many researchers find new inspiration and continue to advance research. If research is not encouraged and promoted, the number of research papers and publications will decrease, which will eventually result in an uncertain future and the loss of the impetus to new research projects.

Thus, it is hoped that researchers actively participate in the 2020 General Conference, explore new research topics required for the era of the 4th Industrial Revolution, conduct various studies, and publish a large number of quality papers through the Journal of Korean Academy of Oral Health.

September 2020 


\section{연구, 논문작성, 게재를 한다는 것의 의미 \\ 마득상}

대한예방치과 · 구강보건학회 회장

2020년도 대한예방치과 · 구강보건학회 종합학술대회의 주제는 “4차 산업혁명시대의 구강보건 및 예방치의학의 접목 탐구(Exploring the integration of public oral health and preventive dentistry in the future industrial revolution)' 입니다. 4차라는 표현이 의미하듯이 4차가 존재하기 위해서는 앞서 1-3차 산업혁명이 있었기 때문입니다.

우리 세대가 존재하는 것은 앞선 세대가 그 토대를 만들어 주었기 때문에 가능했던 것이고, 그런 맥락에서 우리 세대가 또 토대를 만들 어 주어야 다음 세대가 가능할 것입니다. 우리가 연구를 하고 논문을 작성해서 게재를 하는 궁극적인 목표는 무엇일까요? 인류가 건강한 삶을 영위하여 보다 나은 미래, 이 세대보다는 더 나은 다음 세대를 만들어 가기 위함입니다. 게재된 논문을 읽고 많은 연구자들이 새로운 영감을 얻게 되고, 나아가 발전된 연구를 이어가게 됩니다. 연구 활동이 활성화되지 않으면 논문작성 및 게재가 줄어들고, 결국은 새로운 연구 활동의 동력이 상실되고 미래가 불투명해지게 됩니다.

그러한 맥락에서 2020년 종합학술대회에 적극적으로 참여하고 4차 산업혁명시대에 필요한 새로운 연구주제를 탐구하여 다양한 연구 를 진행하고 대한구강보건학회지를 통해 많은 논문들이 게재되길 희망합니다.

2020. 9 . 